\title{
DOPRINOS RAZVIJENOSTI MOTORIČKIH SPOSOBNOSTI KOD SAVLADAVANJA SKIJAŠKE TEHNIKE
}

\author{
Vjekoslav Cigrovski ${ }^{1}$, Igor Božićc i Nikola Prlenda
}

${ }^{1}$ Kineziološki fakultet, Sveučilište u Zagrebu, Hrvatska

${ }^{2}$ Fakultet fizičkog vaspitanja i sporta, Univerzitet u Banjoj Luci, Bosna i Hercegovina

\section{SAŽETAK}

Ovim istraživanjem utvrđen je uticaj motoričkih sposobnosti na proces učenja alpskog skijanja. Takođe, cilj ovog istraživanja bio je utvrditi uticaj određenih morfoloških karakteristika na savladavanje skijaških znanja. Na početku istraživanja ispitanici su bili testirani pomoću testova za procjenu: ravnoteže, agilnosti, eksplozivne i statičke snage, frekvencije pokreta, te fleksibilnosti. Nakon procjene motoričkih sposobnosti, ispitanicima su utvrđene osnovne morfološke karateristike, te su pristupili školi alpskog skijanja u trajanju od sedam dana. Po završetku učenja alpskog skijanja svi ispitanici demonstrirali su sedam elemenata skijaške tehnike ispred pet nezavisnih ispitivača. Analiza rezultata pokazala je kako agilnost pozitivno utiče pri učenju svih ispitanih elemenata skijaške tehnike (kosi spust, $\beta=0,38 ; \beta=0,26$; zavoj ka padini, $\beta=0,33 ; \beta=0,23$; osnovni zavoj, $\beta=0,18$; paralelni zavoj, $\beta=0,32$; vijuganje, $\beta=0,34)$. Rezultati ispitanika u testu izdržaj u čučnju kojim se procjenjuje statička snaga nogu pozitivno utiče kod učenja zavoja ka padini $(\beta=0,19)$, osnovnog zavoja $(\beta=0,35)$, te paralelnog zavoja $(\beta=0,27)$. Test za procjenu ravnoteže (ravnotežni položaj lijeve noge uzdužno) značajno utiče pri učenju osnovnih elemenata skijaške tehnike (kosi spust u desnu stranu, $\beta=0,23$; kosi spust u lijevu stranu, $\beta=0,28$; zavoj ka padini u lijevu stranu, $\beta=0,24)$. Tjelesna visina skijaša početnika negativno utiče na efikasnost usvajanja skijaških znanja $(\beta=-0,5)$, što znači da će višim skijašima biti teže usvajati skijaška znanja u odnosu na niže skijaše. S obzirom na rezultate ovog istraživanja moguće je istaknuti agilnost, statičku snagu, te ravnotežu kao one motoričke sposobnosti koje najviše doprinose skijaškim početnicima prilikom učenja skijaške tehnike.

Ključne riječi: alpsko skijanje, učenje, motoričke sposobnosti, morfološke karakteristike.

\section{UVOD}

Djeca i mladi ljudi svoje slobodno vrijeme sve rjeđe provedu fizički aktivno u prirodnom okruženju, pa je u toj populaciji posljednjih godina zabilježen porast gojaznosti (Benson, Torode i Fiatarone Singh, 2008; Grung, Krause, Siewers, Rieckert i Muller, 2000; Laguna, Ruiz, Lara i Aznar, 2012). Evidentni nedostatak fizičke aktivnosti utiče na cjelokupni sastav tijela, negativno se odražavajući na rast i razvoj (Högström, Pietilä, Nordström i Nordström, 2012). Kod djece su vrlo često zapostavljene ili slabije razvijene motoričke sposobnosti čiji nivo bitno utiče na bolju ili lošiju tehničku uspješnost u svakom sportu, pa tako i u skijanju. Zbog toga je sve naglašenija potreba društva za brigom o fizičkoj aktivnosti mladih, putem koje će se djelovati i na razvoj motoričkih sposobnosti (Cleland i saradnici, 2008). Alpsko skijanje na rekreativnom nivou izrazito je masovan sport (Horterer, 2005) kojim se tokom zimskog perioda aktivno bavi veliki broj porodica. Kako pomoći skijaškim početnicima da lakše nauče skijati pokušaće se odgovoriti u ovom radu. Dio skijaških početnika odustane od daljeg učenja skijanja zbog straha od povrede, koji, između ostalog, može biti izazvan brzinom kretanja na skijama, čestim narušavanjem ravnoteže ili visinom skijaških žičara. Međutim, svakako dio skijaša odustaje od daljeg učenja zbog prethodne neadekvatne kondicionomotoričke pripremljenosti. Prilikom alpskog skijanja čovjek se kreće na specifičan način, koji se vrlo rijetko 
pojavljuje u svakodnevnom kretanju, te je zbog toga i pravilna kondiciona priprema skijaša početnika teža. Poznato je da neke motoričke sposobnosti u većoj mjeri od drugih učestvuju prilikom alpskog skijanja (Dolenec i Žvan, 2001; Emeterio i González-Badillo, 2010; Neumayr i saradici, 2003). Isto tako istraživanja su pokazala da iste motoričke sposobnosti u istom odnosu ne utiču jednako na sportski rezultat kod skijaša takmičara kao i na efikasnost učenja skijanja kod skijaša rekreativnog nivoa (Cigrovski, Matković i Matković, 2008a, 2008b; Cigrovski, Bilić, Prlenda i Martinčević, 2010; Gross i saradnici, 2010; Maffiuletti, Jordan, Spring, Impellizzeri i Bizzini, 2009; Oreb, Vlašić, Cigrovski, Prlenda i Radman, 2011). S obzirom na dokazani različiti udio pojedinih motoričkih sposobnosti kod skijaša takmičara i kod skijaša rekreacijskog nivoa, ovim istraživanjem želja je utvrditi koje motoričke sposobnosti doprinose usvajanju elemenata skijaške tehnike kod skijaških početnika. Isto tako ovim radom pokušaće se utvrditi uticaj nekih morfoloških karakteristika na efikasnost sticanja skijaških znanja.

\section{METODE}

U ovom istraživanju učestvovalo je 86 ispitanika, životne dobi od 22,76 \pm 1,15 godina. Svi ispitanici bili su muškoga pola i skijaški početnici, što znači bez prethodnog iskustva u alpskom skijanju. Za potrebe ovoga istraživanja odabrano je sedamnaest testova za procjenu motoričkih sposobnosti ispitanika. Svi primijenjeni testovi za procjenu motoričkih sposobnosti provedeni su prema standardizovanom postupku mjerenja, a izabrani su zbog svojih dobrih metrijskih karakteristika (Bosco, 1997; Reid, Johnson, Kipp, Albert i White, 1997). Korišćeni testovi su: bočna agilnost dokorakom (MAGKUS), čeona agilnost (MAG9NN), vertikalni skok iz čučnja (MESSJ), vertikalni skok s pripremom (MESCM), skok u dalj iz mjesta (MESSDM), bacanje medicinke od $3 \mathrm{~kg}$ iz ležanja (MESBML3), taping nogom - 15 sekundi (MFRTAN), "cating" - 15 sekundi (MFRCAT), podizanje trupa u 60 sekundi (MRSPT6), izdržaj u čučnju (MSSIC), "sit and reach" (MFLSAR), ravnotežni položaj lijeve noge uzdužno (MRU10L), ravnotežni položaj desne noge uzdužno (MRU10D), ravnotežni položaj lijeve noge poprečno (MRP10L), ravnotežni položaj desne noge poprečno (MRP10D), trčanje 20 m (MES20M) te "hexagon" (MAGHEX). Morfološke karakteristike koje su praćene u ovom istraživanju mjerene su prema uputstvima i propisima Međunarodnog biološkog programa (IBP-International Biological Program). Taj program sastoji se od 39 mjera (Mišigoj-
Duraković, 2008), od kojih su za potrebe ovoga istraživanja korištene: visina tijela (VISINA), masa tijela (MASA), procenat tjelesne masti (\% MASTI) te obim desne natkoljenice (OPSNATD). Proces učenja alpskog skijanja trajao je sedam dana za sve ispitanike. Tokom perioda od sedam dana ispitanici su imali jednake uslove vezano uz: broj ispitanika u pojedinoj skijaškoj grupi (10), broj časova učenja tokom svakoga dana (4), broj časova vježbanja tokom svakoga dana (2), kvalitet i adekvatnost skijaške opreme, kvalitet učitelja skijanja, te adekvatnost skijaških terena. Nakon procesa učenja svi ispitanici spojeni su u jednu grupu, te su prema abecednom redu ispred nezavisnih ispitivača demonstrirali 7 elemenata skijaške tehnike koje su prethodno usvajali tokom procesa učenja. $\mathrm{Na}$ osnovu dobijenih ocjena za demonstraciju: spusta koso u lijevu stranu (KSL), spusta koso u desnu stranu (KSD), zavoja ka padini u lijevu stranu (ZKBL), zavoja ka padini u desnu stranu (ZKBD), osnovnih zavoja (OZ), paralelnih zavoja (PZ), te vijuganja (V), utvrđen je usvojeni nivo skijaškog znanja za svakog ispitanika. Ocjenjivanje ispitanika vršeno je ocjenama od jedan do pet, gdje jedan predstavlja najmanji, a pet najveći nivo usvojenog skijaškog znanja. Budući da rezultati ovog istraživanja značajno zavise od učitelja skijanja, te ocjenjivača, posebna pažnja usmjerena je prilikom njihovog izbora. Svaki pojedini učitelj i ispitivač uključen u ovo istraživanje dobio je detaljna uputstva o načinu podučavanja skijaških početnika, te načinu i kriterijumima ocjenjivanja. Prilikom prikupljanja podataka korišćen je standardizovani postupak ocjenjivanja skijaških znanja (Cigrovski i saradnici, 2008a, 2008b). Podaci u ovom istraživanju obrađeni su regresijskom analizom s ciljem utvrđivanja uticaja prediktorskog skupa testova za procjenu motoričkih sposobnosti i utvrđenih morfoloških karakteristika na nivo usvojenog skijaškog znanja. Za utvrđivanje ukupnog skijaškog znanja korišćena je faktorska analiza. Prikupljeni podaci obrađeni su pomoću statističkoga paketa "Statistica 8.0". Dobijeni rezultati smatrani su statistički značajnima pri $p<0,05$.

\section{REZULTATI I DISKUSIJA}

U Tabelama 1 do 7 prikazan je doprinos rezultata u testovima za procjenu razvijenosti motoričkih sposobnosti i utvrđenih morfoloških karakteristika ispitanika na učenje elemenata skijaške tehnike: kosi spust u desnu i lijevu stranu, zavoj ka padini u desnu i lijevu stranu, osnovni zavoj, paralelni zavoj i vijuganje.

Regresijskom analizom izdvojena su četiri testa za procjenu motoričkih sposobnosti, koji statistički značajno doprinose učenju spusta koso. Četiri izdvojena 


\section{TABELA 1}

Requltati regresione analize $\left(R=0,48 ; R^{2}=0,23 ; p=0,00\right)$ izmedu testova za procjenu motorickeih sposobnosti ispitanika, te uturdenih morfoloških karakteristika i uspjeha pri demonstraciji elementa skijaške tehnike kosi spust u desnu stranu

\begin{tabular}{lrrrr}
\hline & \multicolumn{1}{c}{$\mathrm{B}$} & \multicolumn{1}{c}{$S E$} & \multicolumn{1}{c}{$\beta$} & \multicolumn{1}{c}{$p$} \\
\hline MFRCAT & $-0,08$ & 0,03 & $-0,31$ & $\mathbf{0 , 0 1}$ \\
\hline MRSPT6 & 0,02 & 0,01 & 0,20 & 0,07 \\
\hline MRU10L & 0,01 & 0,00 & 0,23 & $\mathbf{0 , 0 3}$ \\
\hline MAGHEX & 0,22 & 0,06 & 0,38 & $\mathbf{0 , 0 0}$ \\
\hline
\end{tabular}

Legenda: MFRCAT - "Cating" - 15 sekundi; MRSPT6 - Podizanje trupa u 60 sekundi;

MRU10L - Ravnotežni položaj lijeve noge uzdužno; MAGHEX - "Hexagon"; B -

Nestandardizovani koeficijent parcijalne regresije; SE - Standardna greška procjene B koeficijenta; $\beta$ - Standardizovani, parcijalni, regresioni koeficijent; $\mathbf{p}$ - Vjerovatnoća.

\section{TABELA 2}

Rezultati regresione analize $\left(R=0,45 ; R^{2}=0,25 ; p=0,00\right)$ izmedu testova za procjenu motoričkih sposobnosti ispitanika, te uturdenih morfoloških karakteristika i uspjeba pri demonstraciji elementa skijaške tebnike kosi spust u lijevu stranu.

\begin{tabular}{lrrrc}
\hline & \multicolumn{1}{c}{$\mathrm{B}$} & \multicolumn{1}{c}{$S E$} & \multicolumn{1}{c}{$\beta$} & \multicolumn{1}{c}{$p$} \\
\hline MFRCAT & $-0,07$ & 0,03 & $-0,25$ & $\mathbf{0 , 0 3}$ \\
\hline MRSPT6 & 0,03 & 0,01 & 0,30 & $\mathbf{0 , 0 1}$ \\
\hline MRU10L & 0,01 & 0,00 & 0,28 & $\mathbf{0 , 0 1}$ \\
\hline MAGHEX & 0,16 & 0,07 & 0,26 & $\mathbf{0 , 0 2}$ \\
\hline
\end{tabular}

Legenda: MFRCAT - "Cating" - 15 sekundi; MRSPT6 - Podizanje trupa u 60 sekundi; MRU10L - Ravnotežni položaj lijeve noge uzdužno; MAGHEX - "Hexagon"; B Nestandardizovani koeficijent parcijalne regresije; SE - Standardna greška procjene B koeficijenta; $\beta$ - Standardizovani, parcijalni, regresioni koeficijent; $\mathbf{p}$ - Vjerovatnoća.

\section{TABELA 3}

Rezultati regresione analize $\left(\mathrm{R}=0,57 ; \mathrm{R}^{2}=0,32 ; p=0,00\right)$ testova za procjenu motorickeih sposobnosti ispitanika, te utvrdenih morfoloskeib karakteristika i uspjeha pri demonstraciji elementa skijaške tehnike zavoj ka padini u desnu stranu.

\begin{tabular}{lrrrr}
\hline & \multicolumn{1}{c}{$\mathrm{B}$} & \multicolumn{1}{c}{$S E$} & \multicolumn{1}{c}{$\beta$} & \multicolumn{1}{l}{$p$} \\
\hline MAGKUS & 0,36 & 0,13 & 0,26 & $\mathbf{0 , 0 1}$ \\
\hline MFRTAN & $-0,09$ & 0,04 & $-0,24$ & $\mathbf{0 , 0 3}$ \\
\hline MRSPT6 & 0,02 & 0,01 & 0,18 & 0,07 \\
\hline MES20M & 0,63 & 0,37 & 0,16 & $\mathbf{0 , 0 1}$ \\
\hline MAGHEX & 0,19 & 0,06 & 0,33 & $\mathbf{0 , 0 0}$ \\
\hline HEIGHT & $-0,05$ & 0,02 & $-0,50$ & $\mathbf{0 , 0 0}$ \\
\hline MASS & 0,03 & 0,01 & 0,34 & $\mathbf{0 , 0 2}$ \\
\hline
\end{tabular}

Legenda: MAGKUS - Bočna agilnost dokorakom; MFRTAN - Taping nogom-15 sekundi; MRSPT6 - Podizanje trupa u 60 sekundi; MES20M - Trčanje 20 m; MAGHEX "Hexagon"; HEIGHT - Visina tijela; MASS - Težina tijela; B - Nestandardizovani koeficijent parcijalne regresije; SE - Standardna greška procjene B koeficijenta; $\beta$ Standardizovani, parcijalni, regresioni koeficijent; p - Vjerovatnoća. 


\section{TABELA 4}

Rezultati regresione analize $\left(R=0,43 ; R^{2}=0,19 ; p=0,00\right)$ testova za

procjenu motorickeih sposobnosti ispitanika, te uturdenih morfoloških karakteristika

i uspjeha pri demonstraciji elementa skijaške tehnike zavoj ka padini u liveu stranu.

\begin{tabular}{lllll}
\hline & $\mathrm{B}$ & $S E$ & $\beta$ & $p$ \\
\hline MRSPT6 & 0,02 & 0,01 & 0,21 & 0,06 \\
\hline MSSIC & 0,00 & 0,00 & 0,19 & $\mathbf{0 , 0 5}$ \\
\hline MRU10L & 0,01 & 0,00 & 0,24 & $\mathbf{0 , 0 3}$ \\
\hline MAGHEX & 0,13 & 0,06 & 0,23 & $\mathbf{0 , 0 3}$ \\
\hline
\end{tabular}

Legenda: MRSPT6 - Podizanje trupa u 60 sekundi; MSSIC - Izdržaj u čučnju; MRU10L

- Ravnotežni položaj lijeve noge uzdužno; MAGHEX - "Hexagon"; B - Nestandardizovani koeficijent parcijalne regresije; SE - Standardna greška procjene B koeficijenta; $\beta$ - Standardizovani, parcijalni, regresioni koeficijent; $\mathbf{p}$ - Vjerovatnoća.

\section{TABELA 5}

Rezultati regresione analize $\left(R=0,47 ; R^{2}=0,22 ; p=0,00\right)$ testova za procjenu motoričkih sposobnosti ispitanika i uspjeha pri demonstraciji elementa skijaške tehnike osnovni zavoj.

\begin{tabular}{lrrrr}
\hline & \multicolumn{1}{c}{ B } & \multicolumn{1}{c}{$S E$} & $\beta$ & $p$ \\
\hline MSSIC & 0,01 & 0,00 & 0,35 & $\mathbf{0 , 0 0}$ \\
\hline MES20M & $-0,88$ & 0,48 & $-0,18$ & 0,07 \\
\hline MAGHEX & 0,12 & 0,07 & 0,18 & 0,09 \\
\hline
\end{tabular}

Legenda: MSSIC - Izdržaj u čučnju; MES20M - Trčanje 20 m; MAGHEX - "Hexagon"; B

- Nestandardizovani koeficijent parcijalne regresije; SE - Standardna greška procjene B koeficijenta; $\beta$ - Standardizovani, parcijalni, regresioni koeficijent; $\mathbf{p}$ - Vjerovatnoća.

\section{TABELA 6}

Rezultati regresione analize $\left(\mathrm{R}=0,47 ; \mathrm{R}^{2}=0,22 ; p=0,00\right)$ testova za procjenu motoričkih sposobnosti ispitanika i uspjeha pri demonstraciji elementa skijaške tehnike paralelni zavoj.

\begin{tabular}{lcccc}
\hline & $\mathrm{B}$ & $S E$ & $\beta$ & $p$ \\
\hline MAG9NN & 0,34 & 0,16 & 0,22 & $\mathbf{0 , 0 3}$ \\
\hline MSSIC & 0,00 & 0,00 & 0,27 & $\mathbf{0 , 0 1}$ \\
\hline MAGHEX & 0,20 & 0,07 & 0,32 & $\mathbf{0 , 0 0}$ \\
\hline
\end{tabular}

Legenda: MAG9NN - Čeona agilnost; MSSIC - Izdržaj u čučnju; MAGHEX - "Hexagon"; B - Nestandardizovani koeficijent parcijalne regresije; SE - Standardna greška procjene B koeficijenta; $\boldsymbol{\beta}$ - Standardizovani, parcijalni, regresioni koeficijent); $\mathbf{p}$ - Vjerovatnoća.

testa objašnjavaju $23 \%$, odnosno $20 \%$ zajedničkog varijabiliteta pri učenju spusta koso $\left(R^{2}=0,23 ; R^{2}=\right.$ $0,20)$, a najveći zasebni uticaj na usvajanje spusta koso ima rezultat ispitanika u testu hexagon $(\beta=0,38 ; \beta=$ $0,26)$. Kako se elementi spust koso u lijevu i desnu stranu izvode statički, bez dodatnih kretanja skijaša tokom njegovog izvođenja, za očekivati je da rezultati ispitanika u testovima za procjenu statičke ravnoteže značajno utiču na njihovo usvajanje $(\beta=0,23 ; \beta=$ $0,28)$. Povezanost ravnoteže s uspjehom pri učenju osnovnih elemenata skijaške tehnike kod skijaških početnika utvrđena je i u istraživanja Mallioua i saradnika (2004), čija eksperimentalna grupa je osim učenja osnove skijaške tehnike imala i treninge za razvoj ravnoteže. Kostelić (2005) u svom radu takođe naglašava kako ravnoteža vjerovatno najviše razlikuje one koji 


\section{TABELA 7}

Rezultati regresione analize $\left(R=0,52 ; R^{2}=0,27 ; p=0,00\right)$ testova za procjenu motorickih sposobnosti ispitanika te uturdenih morfoloških karakteristika i uspjeha pri demonstraciji elementa skijaške tehnike vijuganje.

\begin{tabular}{lrrrc}
\hline & \multicolumn{1}{c}{$\mathrm{B}$} & \multicolumn{1}{c}{$S E$} & $\beta$ & \multicolumn{1}{c}{$p$} \\
\hline MAGKUS & 0,43 & 0,17 & 0,26 & $\mathbf{0 , 0 2}$ \\
\hline MAG9NN & 0,44 & 0,18 & 0,26 & $\mathbf{0 , 0 2}$ \\
\hline MAGHEX & 0,24 & 0,07 & 0,34 & $\mathbf{0 , 0 0}$ \\
\hline HEIGHT & $-0,03$ & 0,01 & $-0,24$ & $\mathbf{0 , 0 4}$ \\
\hline \%FAT & $-0,08$ & 0,04 & $-0,34$ & $\mathbf{0 , 0 3}$ \\
\hline OPSNATD & 0,07 & 0,04 & 0,33 & $\mathbf{0 , 0 5}$ \\
\hline
\end{tabular}

Legenda: MAGKUS - Bočna agilnost dokorakom; MAG9NN - Čeona agilnost;

MAGHEX - "Hexagon"; HEIGHT - Visina tijela; \%FAT - Postotak tjelesne masti;

OPSNATD - Obim desne nadkoljenice; B - Nestandardizovani koeficijent parcijalne regresije; SE - Standardna greška procjene B koeficijenta; $\beta$ - Standardizovani, parcijalni, regresioni koeficijent; $\mathbf{p}$ - Vjerovatnoća.

\section{TABELA 8}

Rezultati faktorske analize.

\begin{tabular}{ccrc}
\hline $\begin{array}{c}\text { Komponente } \\
\text { (Faktori) }\end{array}$ & $\begin{array}{c}\text { Karakteristična } \\
\text { vrijednost }\end{array}$ & $\begin{array}{c}\% \\
\text { varijanse }\end{array}$ & $\begin{array}{c}\text { Kumulativni } \\
\%\end{array}$ \\
\hline 1 & 4,36 & 62,26 & 62,26 \\
\hline 2 & 0,91 & 13,00 & 75,26 \\
\hline 3 & 0,63 & 8,96 & 84,22 \\
\hline 4 & 0,47 & 6,67 & 90,89 \\
\hline 5 & 0,26 & 3,71 & 94,60 \\
\hline 6 & 0,21 & 2,95 & 97,55 \\
\hline 7 & 0,17 & 2,45 & 100,00 \\
\hline
\end{tabular}

\section{TABELA 9}

Rezultati regresione analize $\left(\mathrm{R}=0,48 ; \mathrm{R}^{2}=0,23 ; p=0,00\right)$ testova za procjenu motorickih sposobnosti ispitanika i usvojenog skijaškog znanjaj.

\begin{tabular}{lcccc}
\hline & $\mathrm{B}$ & $S E$ & $\beta$ & $p$ \\
\hline MSSIC & 0,00 & 0,00 & 0,21 & $\mathbf{0 , 0 4}$ \\
\hline MRU10L & 0,01 & 0,00 & 0,21 & $\mathbf{0 , 0 4}$ \\
\hline MAGHEX & 0,29 & 0,08 & 0,35 & $\mathbf{0 , 0 0}$ \\
\hline
\end{tabular}

Legenda: MSSIC - Izdržaj u čučnju; MRU10L - Ravnotežni položaj lijeve noge uzdužno;

MAGHEX - "Hexagon"; B - Nestandardizovani koeficijent parcijalne regresije; SE

- Standardna greška procjene B koeficijenta; $\beta$ - Standardizovani, parcijalni, regresioni koeficijent; p - Vjerovatnoća.

će brže naučiti skijati od onih koji će skijašku tehniku usvojiti nešto sporije.

Od svih korišćenih testova za procjenu motoričkih sposobnosti najveći uticaj na usvajanje elementa zavoj ka padini imaju testovi za procjenu agilnosti (bočna agilnost dokorakom $\beta=0,26$ te hexsagon $\beta=0,33$; $\beta=0,23)$. Osim testova za procjenu motoričkih sposobnosti kod zavoja ka padini u desnu stranu izdvojena je tjelesna visina i masa, kao morfološke mjere koje značajno utiču na nivo usvojenog znanja ovog elementa. S obzirom da je dobijeni rezultat kod tjelesne visine negativnog predznaka, za pretpostaviti 
je kako ona obrnuto proporcionalno utiče na brzinu usvajanja skijaške tehnike. Dobijene podatke moguće je objasniti činjenicom kako je kod visokih skijaša težište tijela udaljenije od snježne podloge u odnosu na niže skijaše, pa zbog toga lakše narušavaju ravnotežni položaj, te ga nakon narušavanja ponovno teže uspostavljaju prilikom kretanja niz skijašku padinu. Osim negativnog uticaja visine tijela skijaša na ravnotežu, ona negativno utiče i na koordinaciju što znači da će višim skijašima biti teže usvajati skijaška znanja u odnosu na niže skijaše (Dolenec i Žvan, 2001). Za razliku od visine tijela, masa skijaša pozitivno utiče na nivo usvojenog znanja zavoja ka padini. Utvrđen pozitivan doprinos mase tijela moguće je objasniti neophodnim kontinuiranim pritiskom tijela skijaša na vanjsku skiju tokom izvođenja zavoja ka padini. Za očekivati je kako će oni skijaši koji imaju veću tjelesnu masu lakše učiniti potreban pritisak tijela preko skija na snježnu podlogu. Važno pravilo korektno izvedenog zavoja je da skijaš težinu tijela većinom ili u potpunosti mora prebaciti na vanjsku skiju (Matković, Ferenčak i Žvan, 2004), a zavoj ka padini jedan je od prvih zavoja koji skijaški početnik usvaja. Stoga je logičan pozitivan doprinos rezultata u testu ravnotežni položaj lijeve noge uzdužno na klupici za ravnotežu kod učenja zavoja ka padini.

Osnovni zavoj, paralelni zavoj, te vijuganje su elementi skijaške tehnike u kojima skijaš u kontinuitetu povezuje više zavoja, pa se kod njihovog izvođenja znatno više angažuju mišići nogu, u odnosu na spust koso i zavoj ka padini, koji se izvode samo u lijevu ili desnu stranu. Tri izdvojena testa za procjenu motoričkih sposobnosti ispitanika objašnjavaju $22 \%$ zajedničkog varijabiliteta pri učenju osnovnog zavoja $\left(R^{2}=0,22\right)$, a najveći pojedinačni uticaj na usvajanje osnovnog zavoja ima rezultat ispitanika u testu za procjenu statičke snage mišića nogu $(\beta=0,35)$. Dobijeni rezultati potvrđuju kako je kod učenja i usavršavanja elemenata skijaške tehnike, gdje se povezuje više zavoja u kontinuitetu neophodna snaga mišića natkoljenice i potkoljenice.

Paralelni zavoj je najbolji predstavnik skijaške tehnike u širem koridoru, koji skijaši najčešće koriste prilikom savladavanja padine. Uvidom u dobijene rezultate moguće je istaknuti agilnost (čeona agilnost, $\beta=0,22$; hexsagon, $\beta=0,32$ ), te statičku snagu (izdržaj u čučnju, $\beta=0,27$ ), koje od svih motoričkih sposobnosti najviše doprinose učenju paralelnog zavoja.

Vijuganje po definiciji predstavlja kontinuirano povezivanje kratkih, nedovršenih, paralelnih zavoja (Matković i saradnici, 2004), te će opisani element skijaš brže usvojiti ako ima razvijenu agilnost. Sposobnost brze promjene pravca kretanja kod ispitanika procijenjena s tri testa (bočna agilnost dokorakom $(\beta=0,26)$, čeona agilnost $(\beta=0,26)$ i hexagon $(\beta=0,34)$, koji značajno utiču na usvajanje vijuganja.

Uvidom u rezultate regresione analize moguće je uočiti kako se test hexagon za procjenu agilnosti sistematski pojavljuje kod učenja svih elemenata skijaške tehnike. Kako su dosadašnja istraživanja dokazala da eksplozivna snaga nogu od svih motoričkih sposobnosti ima najveći uticaj na uspjeh takmičara u alpskom skijanju (Bocco, 1997; Reid i saradnici, 1997), tako je moguće pretpostaviti kako je agilnost motorička sposobnost koja izrazito doprinosi učenju osnova skijaške tehnike.

Dosadašnja istraživanja definisala su poredak motoričkih sposobnosti po važnosti za alpske skijaše bilo takmičarskog, bilo rekreacijskog nivoa (Neumayr i saradnici, 2003). Najveći uticaj na razvoj pojedine motoričke sposobnosti moguće je ostvariti adekvatnim treningom, korišćenjem specifičnih, usmjerenih vježbi koje će podstaći podizanje nivoa određene motoričke sposobnosti. Međutim, na one motoričke sposobnosti koje su izrazito važne za skijanje moguće je uticati i sistemskim skijanjem. Ali, kako skijaši rekreacionog nivoa u pravilu kontinuirano skijaju 6, odnosno 7 dana pretpostavka je da u tako kratkom periodu nije moguće znatnije uticati na razvoj onih motoričkih sposobnosti koje su važne za skijanje. Stoga je logična preporuka skijašima i onima koji će to tek postati da se prije početka škole skijanja adekvatno za nju fizički pripreme. Kako bi se mogli kvalitetno kondiciono pripremiti, skijaši definitivno moraju razvijati agilnost, statičku snagu mišića nogu i ravnotežu, jer one izrazito utiču na efikasnost učenja skijanja. Nerazvijenost motoričkih sposobnosti definitivno ima određeni negativan uticaj na uspješnost usvajanja elemenata skijaške tehnike. Na razvoj motoričkih sposobnosti koje su izrazito zastupljene prilikom skijanja moguće je uticati pomoću usmjerenih vježbi koje se najčešće ne izvode na skijaškom terenu. Ali, uticati na bitne motoričke sposobnosti za skijanje moguće je, osim pripreme u specijalizovanim fitnes centrima, baveći se specifičnim fizičkim aktivnostima poput rolanja. Naime, tokom rolanja čovjek čini gotovo identična kretanja kao i prilikom izvođenja vijuganja (Roman, Miranda, Martinez i Viciana, 2009; Takahashi i Yoneyama, 2001), te se zbog toga rolanje preporučuje u periodu pripreme za odlazak na skijanje. Kvalitetnom kondicionom pripremom, osim što će se uticati na brzinu usvajanja skijaške tehnike, uticaće se i na smanjenje mogućih povreda prilikom skijanja (Koehle, Loyd-Smith, \& Taunton, 2002, 2002).

Faktorskom analizom izračunata je matrica glavnih komponenti na osnovu ostvarenih ocjena ispitanika 
na sedam elemenata skijaške tehnike.

$\mathrm{Na}$ osnovu izračunatih svojstvenih vrijednosti uz pomoću GK kriterija izolovan je jedan značajni faktor $(\lambda=4,36)$. Moguće je pretpostaviti da dobijeni faktor predstavlja skijaško znanje, jer najviše objašnjava ukupnu varijansu sedam elemenata skijaške tehnike $(62,26 \%)$.

$\mathrm{Na}$ varijabli dobijenoj faktorskom analizom izdvojila su se tri testa za procjenu motoričkih sposobnosti koja utiču na usvajanje skijaškog znanja kod početnika. Kao i kod analiziranih elemenata skijaške tehnike ističe se doprinos $(\beta=0,35)$ testa hexagon, na osnovu čega je procijenjena agilnost ispitanika. Dobijeni rezultati samo potvrđuju uticaj agilnosti na nivo usvojenog skijaškog znanja.

\section{ZAKLJUČAK}

Kako je konfiguracija svakog skijaškog terena drugačija, te kako su trenutni snježni uslovi na njima jedinstveni, skijaš u svakom trenutku savladavanja padine koristi svoje motoričke sposobnosti koje zajedno sa stečenim skijaškim znanjem učestvuju u upravljanju skijama. Od procijenjenih motoričkih sposobnosti najveći uticaj prilikom usvajanja skijaških znanja kod skijaških početnika ima agilnost. Statička snaga nogu takođe utiče na proces učenja skijaške tehnike, dok ravnoteža ima značajan uticaj u samom početku učenja, prilikom usvajanja osnovnih elemenata. Pedagoški radnici, učitelji i treneri su sigurno ti koji bi trebali poznavati načine i metode prenošenja skijaškog znanja. Međutim, kada podučavaju specifična skijaška kretanja trebalo bi poštovati uticaj motoričkih sposobnosti na taj proces. Stoga je preporuka skijašima rekretaivnog nivoa ili budućim skijašima da se adekvatno kondiciono-motorički pripreme prije odlaska na skijaške terene.

\section{LITERATURA}

Benson, A. C., Torode, M. E., Fiatarone Singh, \& M. A. (2008). The effect of high - intensity progressive training on adiposity in children: a randomized controlled trial. International Journal of Obesity, 32, 1016-1027. doi:10.1038/ ijo.2008.5; PMid: 18283282

Bosco, C. (1997). Evoluation and planning condition training for alpine skiers. In E. Muller, H. Schwameder, E. Kornexl, and C. Raschner (Eds.), Science and skiing (pp. 229-250). London, UK: E\&FN Spoon.

Cigrovski, V., Matković, B., \& Matković, R. B. (2008a). Evaluation of objectivity and homogeneity of skiing knowledge grading process. In D. Milanović and F. Prot (Eds.), Proceeding book " 5 th International Scientific conference on Kinesiology" (pp. 513-517). Zagreb, HR: Kineziološki fakultet.

Cigrovski, V., Matković, B., \& Matković, R. B. (2008b). Koje motoričke sposobnosti doprinose boljem učenju elemenata skijaške tehnike [Motor skills that lead to better learning elements of ski technique]. In B. Maleš, Đ. Miletić, M. Kondrić, and M. Kvesić (Eds.), Proceeding book" 3 rd International Conference Contemporary Kinesiology" (pp. 54-59). Split, HR: Faculty of Kinesiology University of Split, Faculty of Natural science, mathematics and education University of Mostar, Faculty of Sport University of Ljubljana.

Cigrovski, V., Bilić, Ž., Prlenda, N., \& Martinčević, I. (2010). The influence of explosive strength on learning of alpine skiing. In S. Simović (Ed), Proceeding book. "2nd International scientific conference Anthropological aspects of sports, physical education and recreation" (pp. 175-179). Banja Luka: Faculty of physical education and sports University of Banja Luka. doi: 10.5550/SP.2.2010.21

Cleland, V., Crawford, D., Baur, L. A., Hume, C., Timperio, A., \& Salmon, J. (2008). A prospective examination of children s time spent outdoors, objectively measured physical activity and overweight. International Journal of Obesity, 32(11), 1685-1693. doi: 10.1038/ijo.2008.171; PMid: 18852701

Dolenec, A., \& Žvan, M. (2001). Competitive success of junior female alpine skiers in light of certain chosen tests of co-ordination. Kinesiologia Slovenica, 7(1-2), 19-22.

Emeterio, C. A., \& González-Badillo, J. J. (2010). The physical and anthropometric profiles of adolescent alpine skiers and their relationship with sporting rank. J Strength Cond Res, 24(4), 1007-1019. doi: 10.1519/JSC.0b013e3181 cbabb5; PMid: 20300026

Gross, M., Lüthy, F., Kroell, J., Müller, E., Hoppeler, H., \& Vogt, M. (2010). Effects of eccentric cycle ergometry in alpine skiers. Int J Sports Med, 31(8), 572-578. doi: 10.1055/s-00301254082; PMid: 20464646

Grung, A., Krause, H., Siewers, M., Rieckert, H., \& Muller, M. J. (2000). Is TV viewing on index of physical activity and fitness in overweight and normal weight children? Public Health Nutrition, 4(6), 1245-1251.

Horterer, H. (2005). Carving skiing. Orthopade, 34(5), 426-458. 
Högström, G.M., Pietilä, T., Nordström, P., \& Nordström, A. (2012). Body composition and performance: influence of sport and gender among adolescents. I Strength Cond Res, 26(7), 1799-1804. doi: 10.1519/JSC.0b013e318237 e8da; PMid: 22728941

Koehle, M. S., Loyd-Smith, R., \& Taunton, E. (2002). Alpine ski injuries and their prevention. Sports Med, 32(12), 785-793. doi: 10.2165/ 00007256-200232120-00003; PMid: 12238941

Kostelić A. (2005). Prikaz i analiza kondicijske pripreme Ivice i Janice Kostelic tijekom sportske karijere (razvoj i rezultati) [Presentation and analysis of traning Ivica and Janica Kostelic during sports career (development and results)]. Unpublished graduate work, University of Zagreb, Faculty of Kineziology.

Laguna, M., Ruiz, J. R., Lara, M. T., \& Aznar, S. (2012). Recommended levels of physical activity to avoid adiposity in Spanish children. Pediatr Obes, Epub ahead of print.

Maffiuletti, N. A., Jordan, K., Spring, H., Impellizzeri, F. M., Bizzini, M. (2009). Physiological profile of Swiss elite alpine skiers-a 10-year longitudinal comparison. In E. Müller, S. Lindinger, and T. Stoggl (Eds.), Science and skiing IV (pp. 365-373). Oxford, UK: Meyer and Meyer Sport.

Malliou, P., Amoutzas, K., Theodosiou, A., Gioftsidou, A., Mantis, K., Pylianidis, T., and Kioumourtzoglou, E. (2004). Proprioceptive training for learning downhill skiing. Percept Mot Skills, 99(1),149-203. doi: 10.2466/PMS.99.5. 149-154; doi: 10.2466/pms.99.1.149-154; doi: 10.2466/PMS.99.4.149-154; PMid: 15446640

Matković, B., Ferenčak, S., \& Žvan, M. (2004). Skijajmo zajedno [Go skiing together]. Zagreb,
HR: Europapress holding i FERBOS inženjering.

Mišigoj-Duraković, M. (2008). Kinantropologijabiološki aspekti tjelesnog vježbanja [Kinantropologybiological aspects of physical exercise]. Zagreb, HR: Kineziološki fakultet.

Neumayr, G., Hoertnagl, H., Pfister, R., Koller, A., Eibl, G., \& Raas, E. (2003). Physical and Physiological Factors Associated with Success in Professional Alpine Skiing. International Journal of Sports Medicine, 24(8), 571-575. doi: 10.1055/ s-2003-43270; PMid: 14598192

Oreb, G., Vlašić, J., Cigrovski, V., Prlenda, N., \& Radman, I. (2011). Relationship between rhythm and learning alpine skiing technique. In I.

Prskalo and D. Novak (Eds), Proceeding book "6th FIEP European congress Physical education in the 21st century-pupils competencies" (pp. 640-646). Zagreb, HR: Hrvatski Kineziološki savez.

Reid, R. C., Johnson, S. C., Kipp, R. W., Albert, R.W., and White, A.T. (1997). Validity of sportspecific field tests fot elite and developing alpine ski racers. In E. Muller, H. Schwameder, E. Kornexl, and C. Raschner (Eds.), Science and skiing (pp. 285-296). London, UK: E\&FN Spoon.

Roman, B., Miranda, M. T., Martinez M., \& Viciana, J. (2009). Transfer from inline-skating to alpine skiing learning in physical education. In E. Múller, S. Lindinger, and T. Stoggl (Eds.), Science and skiing IV (pp. 430-438). Oxford, UK: Meyer and Meyer Sport.

Takahashi, M., \& Yoneyama, T. (2001). Basic ski teory and acceleration during ski turn. In E. Müller, S. Lindinger, and T. Stoggl (Eds.), Science and skiing IV (pp. 307-321). Hamburg, DE: Verlag Dr. Kovač.

Primljemo: 14. okotobra 2012 Revision received: 16. decembra 2012 Accepted: 25. decembra 2012

Korespondencija: Dr Vjekoslav Cigrovski Horvaćanski zavoj 15, 10000 Zagreb

Hrvatska

Telefon: 00385915442202 E-mail: vjekoslav.cigrovski@kif.hr 